\title{
PERBEDAAN EFEKTIVITAS PERAWATAN VULNUS LACERATUM (LUKA ROBEK) MENGGUNAKAN BETADINE DAN NaCI TERHADAP KECEPATAN PENYEMBUHAN
}

\author{
${ }^{1}$ Randy Prayogi, ${ }^{1}$ Norma, ${ }^{1}$ O.Lopulalan \\ ${ }^{1}$ Jurusan Keperawatan Poltekkes Kemenkes Sorong \\ email:normaepid@gmail.com
}

\author{
Artikel history \\ Dikirim, Februari $4^{\text {th }}, 2019$ \\ Ditinjau, Februari $19^{\text {th }}, 2019$ \\ Diterima, Juni $13^{\text {th }}, 2019$
}

\begin{abstract}
Vulnus Laceratum or blunt force injuries are very common, this can be caused by many accidents, both workplace accidents and road accidents. The incidence of vulnus laceratum that occurred in 2016 at the Sele Be Solu Regional Hospital was 374 people. This research was conducted to determine differences in the effectiveness of treatment of vulnus laceratum (torn wounds) using betadine and $\mathrm{NaCl}$. This type of research is an experiment using a quasi-experimental design. The number of samples of 20 respondents was done with a Random Probability Sample. The analysis of this study uses the Paired Sample T-Test. And the results of this study are neither Betadine nor $\mathrm{NaCl}$ in the speed of healing of vulnus laceratum (torn sores).
\end{abstract}

Keywords: Vulnus Laceratum, Betadine, $\mathrm{NaCl}$, speed of healing

\begin{abstract}
ABSTRAK
Kejadian Vulnus Laceratum atau luka akibat benda tumpul sangat sering kita jumpai, hal ini dapat disebabkan oleh banyaknya terjadi kecelakaan, baik itu kecelakaan kerja maupun kecelakaan di jalan raya. Angka kejadian vulnus laceratum yang terjadi pada tahun 2016 di RSUD Sele Be Solu adalah 374 orang. Penelitian ini dilakukan untuk mengetahui perbedaan efektivitas perawatan vulnus laceratum (luka robek) menggunakan betadine dan $\mathrm{NaCl}$. Jenis penelitian ini adalah eksperimen menggunakan desain quasi eksperimen. Jumlah sampel 20 responden yang dilakukan dengan Sample Random Probability. Analisa penelitian ini menggunakan uji Paired Sample T- Test. Dan hasil dari penelitian ini adalah betadine maupun $\mathrm{NaCl}$ tidak ada perbedaan dalam kecepatan penyembuhan vulnus laceratum (luka robek).
\end{abstract}

Kata kunci: Vulnus Laceratum, Betadine, NaCl, kecepatan penyembuhan 


\section{PENDAHULUAN}

Angka kejadian cedera seperti lecet atau memar, luka robek (vulnus laceratum) anggota tubuh terputus dan cedera mata menunjukkan kecenderungan pada usia kurang dari satu tahun kejadiannya rendah, angka meningkat di usia muda dan menurun di usia lanjut. Kelompok umur yang mempunyai proporsi tertinggi untuk jenis cedera lecet atau memar pada umur 15-24 tahun, luka robek (vulnus laceratum) pada umur 25-34 tahun, patah tulang pada umur 75 tahun keatas, terkilir pada umur 65-74 tahun, anggota tubuh terputus pada usia produktif (25-54 tahun), cedera mata pada umur 35 - 64 tahun, gagar otak pada umur 65-74 tahun dan jenis cedera lainnya pada umur 75 tahun ke atas ${ }^{1}$.

Luka adalah keadaan hilang/terputusnya kontinuitas jaringan ${ }^{2}$. Setiap proses penyembuhan luka akan terjadi melalui 3 tahapan yang dinamis, saling terkait dan berkesinambungan serta tergantung pada tipe/jenis dan derajat luka. Sehubungan dengan adanya perubahan morfologik, tahapan penyembuhan luka terdiri dari :(1) Fase inflamasi atau eksudasi, (2) Fase proliferasi atau granulasi dan (3) Fase maturasi dan defesiansi.

Vulnus laceratum atau luka robek adalah luka dengan tepi yang tidak beraturan atau compang camping, biasanya karena tarikan atau goresan benda tumpul (Mansjoer, 2002). Vulnus laceratum adalah luka yang terjadi akibat trauma oleh benda yang tidak tajam, misalnya tepi meja, terkena bagian dari kendaraan bermotor dan sebagainya, tapi tidak rata (Sudjatmiko, 2007).

Ini diakibatkan oleh pisau ataupun luka yang diakibatkan benturan benda tumpul.
Dampak atau akibat tidak melakukan perawatan luka adalah terjadinya hematoma, nekrosis jaringan lunak, keloids, scar, dan infeksi ${ }^{3}$.

Kejadian vulnus laceratum atau luka akibat benda tumpul sangat sering kita jumpai, hal ini dapat disebabkan oleh banyaknya terjadi kecelakaan, baik itu kecelakaan kerja maupun kecelakaan di jalan raya. Hanya saja, jumlah pasien yang datang ke pelayanan kesehatan atau rumah sakit semata-mata untuk melakukan perawatan vulnus laceratum tidak tercatat secara pasti, jika ada pasien yang datang ke rumah sakit atau pelayanan kesehatan dengan vulnus laceratum, pada umumnya itu bukanlah keluhan utama, ada keluhan lain yang lebih utama sehingga vulnus laceratum tidak tercatat sebagai diagnosa medis. Perawatan luka adalah suatu tindakan dimana seorang perawat membersihkan luka dan mengganti verban pada luka yang harus dilakukan secara aseptic dan antiseptic, sehingga mikroorganisme tidak masuk ke dalam luka dan tidak terjadi infeksi ${ }^{3}$.

Perawatan luka yang dilakukan oleh perawat di rumah sakit salah satunya dengan $\mathrm{NaCl} 0,9 \%$. Normal salin atau $\mathrm{NaCl} 0,9 \%$ merupakan larutan isotonis aman untuk tubuh, tidak iritan, melindungi granulasi jaringan dari kondisi kering, menjaga kelembaban sekitar luka dan membantu luka menjalani proses penyembuhan. Perawat menggunakan cairan normal salin untuk mempertahankan permukaan luka agar tetap lembab sehingga dapat meningkatkan perkembangan dan migrasi jaringan epitel ${ }^{3}$.

Natrium Klorida $0,9 \%$ adalah larutan fisiologis yang ada di seluruh tubuh, karena 
alasan ini, tidak ada reaksi hipersensitivitas dari natrium klorida. Normal saline aman digunakan untuk kondisi apapun ${ }^{4}$. Natrium klorida mempunyai $\mathrm{Na}$ dan $\mathrm{Cl}$ yang sama seperti plasma. Sel ini tidak akan mempengaruhi sel darah merah. Natrium klorida tersedia dalam beberapa konsentrasi, yang paling sering digunakan Natrium Klorida 0,9\%.

Povidone iodine merupakan salah satu pengobatan luka secara kimiawi yang sering kali digunakan dalam penyembuhan luka. Povidone iodine memiliki efek antimikroba, menciptakan lingkungan lembab, dan dapat menginduksi angiogenesis. Obat ini juga dilaporkan dapat mencegah inflamasi namun povidone iodine $10 \%$ dikatakan pula memiliki efek menghambat pertumbuhan fibroblas pada percobaan kultur sel secara invitro ${ }^{5}$.

Secara umum, povidone iodine mempunyai sifat antiseptik (membunuh kuman) baik bakteri gram positif maupun gram negatif. Akan tetapi povidone iodine juga bersifat iritatif dan lebihtoksik bila masuk ke pembuluh darah. Povidone iodine bersifat bakteriostatik dengan kadar $640 \mu \mathrm{g} / \mathrm{ml}$ dan bersifat bakterisid pada kadar $960 \mu \mathrm{g} / \mathrm{ml}$. Mikobakteria tuberkulosa bersifat resisten terhadap bahan ini. Povidone iodine memiliki toksisitas rendah pada jaringan, tetapi detergen dalam larutan pembersihnya akan lebih meningkat toksisitasnya (Peter, 1992). Dalam 10\% povidone iodine mengandung $1 \%$ iodium yang mampu membunuh bakteri dalam 1 menit dan membunuh spora dam waktu 15 menit $^{7}$.

Dalam penggunaannya dipilih povidone iodine $10 \%$ dikarenakan povidone iodinetinggidalam kosentrasi menyebabkan iritasi kulit. Selain itu povidone iodine dalam penggunaan yangberlebihan dapat menghambat granulasi luka. Dalam perawatan luka secara umum biasanya menggunakan Povidone Iodine $10 \%{ }^{7}$.

Pada bulan Januari 2013 perawatan luka post sectio cesarea di ruang Bougenville RSUD Tugurejo Semarang sebagian mulai menggunakan $\mathrm{NaCl} \quad 0,9 \%$ sebagai larutan pembersih luka maupun sebagai penutup luka. Perawatan luka yang biasa dilakukan pada pasien pasca operasi baik dengan povidon iodine $10 \%$ maupun $\mathrm{NaCl} \quad 0,9 \%$ selama ini belum pernah dilakukan penelitian tentang efektifitas hasil dari cara perawatan luka yang dilakukan ${ }^{6}$.

Penelitian yang dilakukan Rostini dkk (2013) menunjukan bahwa ada pengaruh perawatan luka dengan $\mathrm{NaCl} 0,9 \%$ terhadap lama hari rawat pasien vulnus laceratum. Pasien yang dirawat luka dengan $\mathrm{NaCl} 0,9 \%$ memiliki waktu hari rawat yang lebih cepat. (Dengen etal., 2015) ${ }^{8}$ sedangkan pada penelitian yang dilakukan oleh Istikomah tahun 2010 tentang perbedaan perawatan luka dengan menggunakan povidone iodine $10 \%$ dan $\mathrm{NaCl}$ $0,9 \%$ terhadap proses penyembuhan luka pada pasien post operasi prostatektomi di ruang anggrek RSUD Tugurejo Semarang didapatkan hasil adanya perbedaan proses penyembuhan luka yang signifikan antara pasien post operasi prostaektomi yang diberikan perawatan luka dengan menggunakan povidone $10 \%$ dan $\mathrm{NaCl}$ $0,9 \%$ dengan $\mathrm{p}$ value 0,040 . Dalam hal ini povidone iodine $10 \%$ lebih baik dari $\mathrm{NaCl} 0,9 \%$ di dalam penyembuhan luka ${ }^{9}$. 
Berdasarkan latar belakang penelitian di atas, penulis tertarik mengimplementasikan efektivitas perawatan luka robek (vulnus laceratum) menggunakan betadine dan $\mathrm{NaCl}$ terhadap kecepatan penyembuhan di RSUD Sele Be Solu Kota Sorong. Serta melihat perawatan luka yang dilakukan di IGD, polik bedah dan ruang melati dengan menggunakan larutan betadine dan $\mathrm{NaCl}$ untuk mempercepat lama hari rawat pasien.

Data yang diambil pada tahun 2016 pasien dengan vulnus laceratum di RSUD Sele
Be Solu Kota Sorong dalam setahun berjumlah 374 orang.

\section{METODE}

Desain penelitian ini adalah quasi eksperiment, jumlah sampel sebanyak 20 menggunakan tekniksampel accidental sampling. Data dianilis menggunakan uji independent T-Test. Lokasi penelitian dilakukan di RSUD Sele Be Solu Kota Sorong Pada bulan agustus Tahun 2017.

\section{HASIL}

\section{Univariat}

Tabel 1. Distribusi frekuensi responden berdasarkan pekerjaan pasien vulnus laceratum di ruang poli bedah RSUD Sele Be Solu Kota Sorong tahun 2017

Pekerjaan Responden Jumlah (Orang) Presentase (\%)

\begin{tabular}{ccc}
\hline Supir & 2 & 10 \\
PNS & 2 & 10 \\
Swasta & 7 & 35 \\
Tidak Bekerja & 7 & 35 \\
Tani & 2 & 10 \\
\hline Total & 20 & 100 \\
\hline
\end{tabular}

Tabel 1. menunjukkan gambaran responden berdasarkan pekerjaan. Mayoritas tertingginya adalah swasta dan tidak bekerja yang

Tabel 2. Distribusi frekuensi responden berdasarkan jenis kelamin pasien vulnus laceratum di ruang poli bedah RSUD Sele Be Solu Kota Sorong tahun 2017

\begin{tabular}{ccc}
\hline Jenis Kelamin & Jumlah (Orang) & Presentase $(\%)$ \\
\hline Laki-laki & 15 & 75 \\
Perempuan & 5 & 25 \\
\hline Total & 20 & 100 \\
\hline
\end{tabular}

Tabel 2. menggambarkan jenis kelamin terbanyak pada responden yaitu lakilaki berjumlah 15 orang (75\%) sedangkan perempuan berjumlah 5 orang (25\%). 
Tabel 3. Distribusi frekuensi responden berdasarkan pendidikan pasien vulnus laceratum di ruang poli bedah RSUD Sele Be Solu Kota Sorong tahun 2017

\begin{tabular}{ccc}
\hline Pendidikan & Jumlah (Orang) & Presentase (\%) \\
& & 5 \\
\hline Belum Sekolah & 1 & 20 \\
SD & 4 & 20 \\
SMP & 4 & 55 \\
SMA & 11 & 100 \\
\hline Total & 20 & \\
\hline
\end{tabular}

Tabel 3. menggambarkan pendidikan responden, yang paling terbanyak adalah SMA berjumlah 11 orang (55\%) sedangkan yang paling rendah adalah belum sekolah berjumlah 1 orang $(5 \%)$.

\section{Bivariat}

\section{PEMBAHASAN}

Hasil dari penelitian ini didapatkan bahwa tidak ada perbedaan efektivitas yang signifikan antara kecepatan penyembuhan antara $\mathrm{NaCl}$ maupun Betadine karena memiliki nilai P Value 0,895. Dari 20 responden yang paling banyak mengalami luka robek adalah laki-laki yang berjumlah 15 orang, pendidikan responden yang paling terbanyak adalah SMA berjumlah 11 orang (55\%) pekerjaan Responden Mayoritas tertingginya adalah swasta dan tidak bekerja yang berjumlah 7 orang (35\%) usia mayoritas yang mengalami vulnus laceratum adalah rentang usia 26-35 tahun berjumlah 9 orang $(45 \%)$.

Povidone iodine atau yang juga dikenal sebagai betadine adalah salah satu senyawa kimia yang digunakan dalam pembuatan antiseptik. Sebagai antiseptik, povidone iodine
Setelah dilakukan analis statistic dengan menggunakan uji Independent T-Test, diperoleh hasil $p$ value 0,895>0.005. Menunjukkan bahwa tidak ada perbedaan antara $\mathrm{NaCl}$ dan Betandin terhadap kecepetan penyembuhan luka.

dapat digunakan untuk membersihkan serta mencegah infeksi pada luka dikulit hingga vagina. Obat ini juga berguna sebagai disinfeksi pada luka bakar, serta efektif mengatasi serangan jamur, bakteri penyebab radang tenggorokan, dan virus tertentu, termasuk HIV dan herpes simplex ${ }^{10}$.

Antiseptik ini biasanya dioleskan langsung ke bagian tubuh yang luka, namun tersedia juga dalam bentuk semprot, salep, obat kumur, dan sejenis tisu basah atau swab yang dioleskan pada jaringan dalam atau kulit sebelum dan sesudah pembedahan pada prosedur operasi atau pengambilan darah ${ }^{10}$.

Povidone iodine merupakan salah satu pengobatan luka secara kimiawi yang sering kali digunakan dalam penyembuhan luka. Povidone iodine memiliki efek antimikroba, menciptakan lingkungan lembab, dan dapat 
menginduksi angiogenesis. Obat ini juga dilaporkan dapat mencegah inflamasi namun povidone iodine $10 \%$ dikatakan pula memiliki efek menghambat pertumbuhan fibroblas pada percobaan kultur sel secara invitro ${ }^{10}$.

Povidone iodine telah diperkenalkan dipasaran sebagai antiseptic sekitar tahun lima puluhan dan mempunyai efektivitas terhadap penyakit infeksi yang disebabkan oleh mikroorganisme ${ }^{11}$.

Natrium Klorida 0,9\% adalah larutan fisiologis yang ada di seluruh tubuh, karena alasan ini, tidak ada reaksi hipersensitivitas dari natrium klorida. Normal saline aman digunakan untuk kondisi apapun (Kristianingrum, 2013). Natrium klorida mempunyai $\mathrm{Na}$ dan $\mathrm{Cl}$ yang sama seperti plasma. Sel ini tidak akan mempengaruhi sel darah merah. Natrium klorida tersedia dalam beberapa konsentrasi, yang paling sering digunakan Natrium Klorida $0,9 \%{ }^{11}$.

Normal salin atau $\mathrm{NaCl} \quad 0,9 \%$ merupakan larutan isotonis aman untuk tubuh, tidak iritan, melindungi granulasi jaringan dari kondisi kering, menjaga kelembaban sekitar luka dan membantu luka menjalani proses penyembuhan. Perawat menggunakan cairan normal salin untuk mempertahankan permukaan luka agar tetap lembab sehingga dapat meningkatkan perkembangan dan migrasi jaringan epitel ${ }^{11}$.

Penelitian ini sejalan dengan Lesya setyawati DKK (2013) $)^{12}$ tentang perbedaan penyembuhan luka post section caesare yang dilakukan perawatan luka dengan $\mathrm{NaCl} 0,9 \%$ dan Povidine Iodine 10\% di RSUD Tugu Rejo Semarang yang memiliki nilai $\mathrm{P}$ Value 0,317 yang berarti tidak ada perbedaan yang signifikan antara $\mathrm{Nacl}$ dan Povidine Iodine pada penyembuhan luka post sectio caesare.

\section{SIMPULAN}

Berdasarkan hasil penelitian dan uraian pada bab sebelumnya, maka dapat disimpulkan bahwa hasil dari penelitian ini adalah betadine maupun $\mathrm{NaCl}$ mempunyai kesamaan dalam mempercepat penyembuhan vulnus laceratum (luka robek).

\section{UCAPAN TERIMA KASIH}

Terimakasih peneliti ucapkan kepada direktur RSUD Sele Be Solu Kota Sorong yang telah membantu dalam melakukan penelitian ini.

\section{DAFTAR PUSTAKA}

1. Delima, m. (2013). Hubungan perawatan luka dengan proses penyembuhan luka pada klien luka robek ( vulnus laceratum ) di ruangan bedah rsi ibnu sina bukittinggi tahun 2013.

2. Dwiningsih, s. U., lestari, k. P., \& mellitus, u. D. (2014). Prosiding konferensi nasional ii ppni jawa tengah 2014 efektifitas penyembuhan luka menggunakan nacl $0,9 \%$ dan hydrogel pada ulkus diabetes mellitus di rsu kota semarang, 144-152.

3. Histologi otot fungsi jaringan otot. (n.d.).

4. Ii, b. A. B. (2003). Pdf created with deskpdf pdf writer - trial:: http://www.docudesk.com pdf created with deskpdf pdf writer trial :: http://www.docudesk.com, 624.

5. Metode, p., luka, r., dengan, m., hiperbarik, t., proses, t., luka, p., ... jember, u. (2015). Yoland, septiane 
usiska.

6. Pada, s., mencit, k., atik, n., \& r, j. I. A. (n.d.). Dengan solusio povidone iodine terhadap penyembuhan luka the differences between topical aplication of the aloe vera gel with the povidone iodine solutio for skin wound healing in mice ( mus musculus ).

7. Process, w. H., \& care, w. (n.d.). Proses penyembuhan dan penanganan luka, 1-19.

8. Istikomah tahun 2010. Perbedaan perawatan luka dengan menggunakan povidone iodine $10 \%$ dan $\mathrm{NaCl}$ 0,9\% terhadap proses penyembuhan luka pada pasien post operasi prostatektomi di ruang anggrek RSUD Tugurejo Semarang. Kebidanan, j. (2013). Luka (sjamsuhidajat, 2010)., 2(4), 1-9.

9. Lesya setyawati DKK (2013) Perbedaan penyembuhan luka post section caesare yang dilakukan perawatan luka dengan $\mathrm{NaCl} 0,9 \%$ dan Povidine Iodine $10 \%$ di RSUD Tugu Rejo Semarang. Kebidanan, j. (2013). Luka (sjam- suhidajat, 2010)., 2(4), 1-

10. Program, m., ilmu, s., fakultas, k., kesehatan, i., tribhuwana, u., malang, t., ... malang, t. (2017). Nursing news volume 2, nomor 1 , 2017, 2, 511-523.

11. Putri, s., djamal, a., \& ilmiawati, c. (n.d.). Artikel penelitian perbandingan daya hambat larutan antiseptik povidone iodine dengan ekstrak daun sirih terhadap candida albicans secara in vitro, 4(3), 962 966.

12. Rostini dkk (2013). Pengaruh perawatan luka dengan $\mathrm{NaCl} 0,9 \%$ terhadap lama hari rawat pasien vulnus laceratum. Pasien yang dirawat luka dengan $\mathrm{NaCl} \quad 0,9 \%$ memiliki waktu hari rawat yang lebih cepat. Kebidanan, j. (2013). Luka., 2(4), 1- 